\title{
Erratum
}

\section{The Classic: Integration of Deoxyribonucleic Acid Specific for Rous Sarcoma Virus after Infection of Permissive and Nonpermissive Hosts (RNA tumor viruses/reassociation kinetics/duck cells)}

\author{
Harold E. Varmus, Peter K. Vogt, J. Michael Bishop
}

Published online: 27 May 2009

(C) The Association of Bone and Joint Surgeons $(2009$

\section{Erratum to: Clin Orthop Relat Res DOI 10.1007/s11999-008-0355-8}

In the online version of this article, the affiliations of Harold E. Varmus, Peter K. Vogt, and J. Michael Bishop are not current. They are current as displayed here. Note that Dr. Varmus's correct email address is varmus@mskcc. org.

In the original publication of Varmus HE, Vogt PK, Bishop JM. Integration of deoxyribonucleic acid specific for Rous sarcoma virus after infection of permissive and nonpermissive hosts (RNA tumor viruses/reassociation kinetics/duck cells). Proc Nat Acad Sci USA. 1973; 70:3067-3071, the authors' affiliations were listed as follows:

Harold E. Varmus, J. Michael Bishop

Department of Microbiology, University of California, San Francisco, Calif. 94122

Peter K. Vogt

Department of Microbiology, University of Southern California Medical School, 2025 Zonal Ave., Los Angeles, Calif. 90033

The online version of the original article can be found under doi:10.1007/s11999-008-0355-8.

H. E. Varmus $(\bowtie)$

Memorial Sloan-Kettering Cancer Center, 1275 York Avenue,

New York, NY 10021, USA

e-mail: varmus@mskcc.org

P. K. Vogt

Department of Molecular and Experimental Medicine,

The Scripps Research Institute, La Jolla, CA 92037, USA

J. M. Bishop

HSW 1542, University of California, San Francisco,

San Francisco, CA 94143, USA 